\title{
CROSS-CULTURAL DIFFERENCES IN DRIVER SELF-ASSESSMENT
}

\author{
MichaEL SivaK \\ The University of Michigan, Transportation Research Institute, \\ Ann Arbor, MI 48109-2150, U.S.A. \\ JOSÉ SOLER \\ The University of Valencia, Faculty of Psychology, Valencia, Spain
}

ULRICH TRÄNKLE

The University of Münster, Institute of Psychology, Münster, Federal Republic of Germany

(Received 13 May 1988)

\begin{abstract}
This study investigated differences in driver self-assessment among U.S., Spanish, and West German drivers. Subjects responded to 14 questions that used five-point semantic scales dealing with driver performance and abilities. Pairs of questions, concerning the same driving-related aspects, differed by requesting a self-assessment on an absolute basis and in relation to the average driver. The subjects in all three countries included younger, middle-aged, and older drivers of both sexes. The following are the main findings: (1) a majority of drivers in each country rated themselves positively on all driving-related scales studied; (2) significant effects of country, age group, and sex of the subjects were present for several of the scales; (3) some of these effects remained significant even after controlling for the differential driving experience. For example, U.S. drivers assessed themselves as safer than did West German and Spanish subjects, younger subjects less wise than middle-aged and older subjects, and males more relaxed than females.
\end{abstract}

\section{INTRODUCTION}

This study is one of three studies performed as part of research on cross-cultural differences in driver risk-behavior. The other two studies investigated perception of risk in slide-projected photographs of traffic scenes (Sivak, Soler, Tränkle, and Spagnhol 1989), and simulated driver risk-taking (Sivak, Soler, and Tränkle 1989).

The present study focused on driver self-assessment in the United States, Spain, and West Germany. Previous studies (Svenson 1981; McCormick, Walkey, and Green 1986) have shown that drivers tend to rate themselves as more skillful and less risky than the average driver. The primary objective of the present study was to investigate cross-cultural differences in self-assessment of drivers using semantic scales related to driving ability and performance, both on an absolute basis and in relation to the "average" driver. The secondary objective was to study age- and sex-related differences in driver self-assessment. All of these effects were investigated with and without controlling for the differential driving experience.

\section{METHOD}

\section{Questionnaire}

The questionnaire consisted of 14 questions. Each question had five possible response categories. Questions 1-6 (adapted from McCormick et al. 1986) asked subjects to assess themselves on the following semantic scales: unpredictable-predictable, dangerous-safe, tense-relaxed, foolish-wise, inconsiderate-considerate, and irresponsibleresponsible. All six of these questions used the same basic format, illustrated here by the unpredictable-predictable scale: As a driver I am: very unpredictable, somewhat unpredictable, in between, somewhat predictable, very predictable.

Questions 7-12 dealt with the same six semantic scales as questions 1-6, but this time subjects were asked to assess themselves in comparison to the average driver in one's own country. Again, these six questions used the same basic format, illustrated 
here by the unpredictable-predictable scale: In comparison to the average U.S. (Spanish, West German) driver I am: much more unpredictable, somewhat more unpredictable, about average, somewhat more predictable, much more predictable.

Questions 13 and 14 dealt with driving skills using bad-good semantic scales. Question 13 concerned self-assessment: Rate your driving skills: very bad driver, bad driver, in between, good driver, very good driver. Question 14 dealt with the assessment of the majority of drivers in one's own country: Rate the driving skills of the majority of U.S. (Spanish, West German) drivers: very bad drivers, bad drivers, in between, good drivers, very good drivers.

\section{Subjects}

Sixty subjects were tested in each country, for a total of 180 subjects. In each country there were 20 subjects ( 10 males and 10 females) in each of the following three age groups: 19-21 year olds, 35-45 year olds, and 65-75 year olds. The distribution of ages and driving experiences of subjects in each group are summarized in Table 1.

The U.S. subjects, who were paid for their participation, came primarily from Ann Arbor, Michigan, a city with a population of approximately 120,000 . The Spanish subjects, who participated without reimbursement, came primarily from Valencia, a city with a population of approximately 800,000 . The German subjects came primarily from Münster, a city with a population of approximately 270,000 . All German female middleaged subjects (professional and nonprofessional drivers) and all older subjects were paid for their participation.

\section{Procedure}

The questions were always shown in the same order, with questions 1-6 on the first page, questions 7-12 on the second page, and questions 13 and 14 on the third page. The questionnaire was constructed in English, and then translated into Spanish and German. Subjects took 4-10 minutes to complete the questionnaire.

Table 1. Age and driving experience of subjects

\begin{tabular}{|c|c|c|c|c|c|c|c|c|}
\hline \multirow[b]{2}{*}{ Group } & \multirow[b]{2}{*}{ Country } & \multirow[b]{2}{*}{ Sex } & \multirow[b]{2}{*}{ N } & \multicolumn{3}{|c|}{ Age } & \multicolumn{2}{|c|}{ Experience } \\
\hline & & & & Min & Max & Mean & $\begin{array}{l}\text { Mean } \\
\text { Years of } \\
\text { Driving }\end{array}$ & $\begin{array}{c}\text { Mean } \\
\text { Annual } \\
\mathrm{km}\end{array}$ \\
\hline \multirow[t]{3}{*}{ Younger } & U.S.A. & $\begin{array}{l}\text { Males } \\
\text { Females }\end{array}$ & $\begin{array}{l}10 \\
10\end{array}$ & $\begin{array}{l}19 \\
19\end{array}$ & $\begin{array}{l}21 \\
21\end{array}$ & $\begin{array}{l}20.0 \\
19.9\end{array}$ & $\begin{array}{l}4.3 \\
3.6\end{array}$ & $\begin{array}{r}10,185 \\
6,360\end{array}$ \\
\hline & Spain & $\begin{array}{l}\text { Males } \\
\text { Females }\end{array}$ & $\begin{array}{l}10 \\
10\end{array}$ & $\begin{array}{l}19 \\
19\end{array}$ & $\begin{array}{l}21 \\
21\end{array}$ & $\begin{array}{l}20.0 \\
20.4\end{array}$ & $\begin{array}{l}2.7 \\
1.4\end{array}$ & $\begin{array}{l}5,570 \\
2,970\end{array}$ \\
\hline & $\begin{array}{l}\text { West } \\
\text { Germany }\end{array}$ & $\begin{array}{l}\text { Males } \\
\text { Females }\end{array}$ & $\begin{array}{l}10 \\
10\end{array}$ & $\begin{array}{l}19 \\
19\end{array}$ & $\begin{array}{l}21 \\
21\end{array}$ & $\begin{array}{l}19.8 \\
20.3\end{array}$ & $\begin{array}{l}1.9 \\
2.5\end{array}$ & $\begin{array}{r}16,150 \\
9,460\end{array}$ \\
\hline \multirow[t]{3}{*}{$\begin{array}{l}\text { Middle- } \\
\text { Aged }\end{array}$} & U.S.A. & $\begin{array}{l}\text { Males } \\
\text { Females }\end{array}$ & $\begin{array}{l}10 \\
10\end{array}$ & $\begin{array}{l}35 \\
35\end{array}$ & $\begin{array}{l}45 \\
45\end{array}$ & $\begin{array}{l}39.8 \\
38.9\end{array}$ & $\begin{array}{l}22.0 \\
22.7\end{array}$ & $\begin{array}{l}25,523 \\
19,275\end{array}$ \\
\hline & Spain & $\begin{array}{l}\text { Males } \\
\text { Females }\end{array}$ & $\begin{array}{l}10 \\
10\end{array}$ & $\begin{array}{l}36 \\
35\end{array}$ & $\begin{array}{l}45 \\
45\end{array}$ & $\begin{array}{l}40.0 \\
40.2\end{array}$ & $\begin{array}{l}13.9 \\
12.8\end{array}$ & $\begin{array}{r}27,600 \\
6,800\end{array}$ \\
\hline & $\begin{array}{l}\text { West } \\
\text { Germany }\end{array}$ & $\begin{array}{l}\text { Males } \\
\text { Females }\end{array}$ & $\begin{array}{l}1.0 \\
10\end{array}$ & $\begin{array}{l}36 \\
35\end{array}$ & $\begin{array}{l}44 \\
45\end{array}$ & $\begin{array}{l}39.0 \\
39.8\end{array}$ & $\begin{array}{l}17.0 \\
16.0\end{array}$ & $\begin{array}{r}24,700 \\
7,950\end{array}$ \\
\hline \multirow[t]{3}{*}{ Older } & U.S.A. & $\begin{array}{l}\text { Males } \\
\text { Females }\end{array}$ & $\begin{array}{l}10 \\
10\end{array}$ & $\begin{array}{l}65 \\
66\end{array}$ & $\begin{array}{l}73 \\
74\end{array}$ & $\begin{array}{l}69.4 \\
70.9\end{array}$ & $\begin{array}{l}53.9 \\
51.7\end{array}$ & $\begin{array}{r}16,425 \\
7,246\end{array}$ \\
\hline & Spain & $\begin{array}{l}\text { Males } \\
\text { Females }\end{array}$ & $\begin{array}{l}10 \\
10\end{array}$ & $\begin{array}{l}65 \\
65\end{array}$ & $\begin{array}{l}75 \\
72\end{array}$ & $\begin{array}{l}69.3 \\
68.0\end{array}$ & $\begin{array}{l}27.8 \\
21.6\end{array}$ & $\begin{array}{l}8,830 \\
4,150\end{array}$ \\
\hline & $\begin{array}{l}\text { West } \\
\text { Germany }\end{array}$ & $\begin{array}{l}\text { Males } \\
\text { Females }\end{array}$ & $\begin{array}{l}10 \\
10\end{array}$ & $\begin{array}{l}65 \\
66\end{array}$ & $\begin{array}{l}75 \\
75\end{array}$ & $\begin{array}{l}67.2 \\
69.7\end{array}$ & $\begin{array}{l}35.6 \\
34.1\end{array}$ & $\begin{array}{r}14,400 \\
9,750\end{array}$ \\
\hline
\end{tabular}


Table 2. Distributions of responses by country, and the results of $\chi^{2}$ tests (the response categories 1 through 5 are from the most "negative" to the most "positive" categories; the entries are percentages, but the $\chi^{2}$ tests were performed on the raw frequencies)

\begin{tabular}{|c|c|c|c|c|c|c|c|c|c|c|c|c|c|c|c|}
\hline \multirow{4}{*}{ Scale } & \multicolumn{15}{|c|}{ Country } \\
\hline & \multicolumn{5}{|c|}{ U.S.A. } & \multicolumn{5}{|c|}{ Spain } & \multicolumn{5}{|c|}{ West Germany } \\
\hline & \multicolumn{5}{|c|}{ Response Categories } & \multicolumn{5}{|c|}{ Response Categories } & \multicolumn{2}{|c|}{ Response } & \multicolumn{3}{|c|}{ Categories } \\
\hline & 1 & 2 & 3 & 4 & 5 & 1 & 2 & 3 & 4 & 5 & 1 & 2 & 3 & 4 & 5 \\
\hline Predictable (Absolute)† & 0 & 7 & 10 & 53 & 30 & 0 & 3 & 42 & 33. & 22 & 5 & 8 & 12 & 47 & 28 \\
\hline Safe (Absolute)t & 0 & 2 & 7 & 40 & 52 & 2 & 5 & 28 & 40 & 25 & 0 & 5 & 12 & 37 & 47 \\
\hline Relaxed (Absolute) & 0 & 13 & 23 & 43 & 20 & 2 & 18 & 25 & 32 & 23 & 7 & 12 & 18 & 32 & 32 \\
\hline Wise (Absolute) & 0 & 5 & 12 & 55 & 28 & 2 & 8 & 25 & 27 & 38 & 0 & 5 & 15 & 40 & 40 \\
\hline Considerate (Absolute) & 0 & 3 & 8 & 47 & 42 & 0 & 3 & 27 & 37 & 33 & 0 & 0 & 13 & 48 & 38 \\
\hline Responsible (Absolute) $\dagger$ & 0 & 0 & 3 & 32 & 65 & 0 & 2 & 20 & 30 & 48 & 0 & 0 & 5 & 45 & 50 \\
\hline Predictable (Relative) & 2 & 2 & 27 & 58 & 12 & 0 & 2 & 38 & 42 & 18 & 3 & 7 & 32 & 47 & 12 \\
\hline Safe (Relative)† & 0 & 0 & 8 & 62 & 30 & 0 & 0 & 32 & 47 & 22 & 0 & 8 & 35 & 43 & 13 \\
\hline Relaxed (Relative) & 0 & 15 & 38 & 27 & 20 & 3 & 12 & 37 & 35 & 13 & 0 & 17 & 25 & 42 & 17 \\
\hline Wise (Relative) & 0 & 3 & 27 & 50 & 20 & 0 & 2 & 32 & 45 & 22 & 0 & 5 & 28 & 45 & 22 \\
\hline Considerate (Relative)† & 0 & 2 & 17 & 57 & 25 & 0 & 0 & 33 & 47 & 20 & 0 & 3 & 20 & 55 & 22 \\
\hline Responsible (Relative) & 0 & 2 & 17 & 53 & 28 & 0 & 2 & 30 & 42 & 27 & 0 & 2 & 25 & 52 & 22 \\
\hline Driving Skills (Absolute) & 0 & 0 & 10 & 68 & 22 & 0 & 3 & 47 & 80 & 10 & 0 & 2 & 30 & 67 & 2 \\
\hline Driving Skills (Majority) & 0 & 10 & 60 & 30 & 0 & 5 & 10 & 65 & 20 & 0 & 0 & 12 & 52 & 37 & 0 \\
\hline
\end{tabular}

$+x^{2}$ significant at $\mathrm{Q}<0.05$.

\section{RESULTS}

The distributions of responses by country to each of the 14 questions are shown in Table 2. Differences in these distributions were examined by performing a separate $\chi^{2}$ test on the cell frequencies for each question. The results of these analyses are also presented in Table 2.

The results of a series of analyses of variance are shown in Table 3 . The main factors in these analyses were country, age group, and sex, with the dependent variables being the responses on the questions. The responses for these analyses of variance (and for the subsequent analyses of covariance) were coded by assigning numbers 1 through 5 to the five response categories, from the most "negative" to the most "positive" response category. Out of 56 interactions, only 4 were statistically significant: country by age group (predictable, absolute scale), country by sex (safe, absolute scale), and country by age group by sex (considerate, absolute scale and responsible, relative scale).

Since driving experience varied substantially across the subject groups (see Table 1), a series of analyses of covariance was performed to control for the effects of the driving experience. The independent variables in these analyses were country, age group, and sex, while the covariates were years of driving experience and annual amount of driving. The results of these analyses are also presented in Table 3.

\section{DISCUSSION}

Overall pattern of responses

A majority of subjects in each of the three countries viewed themselves positively on all driving-related scales studied. This finding is in agreement with previous studies, 
Table 3. Means by country, age group, and sex, and the results of the analyses of variance and covariance; means of the significant main effects $(p<0.05)$ in the analyses of variance are in hold numbers; underlined means indicate that these main effects remained significant even after controlling for the driving experience in the analyses of covariance (the adjusted means were generally different from the shown unadjusted means, but for all significant effects the order of means remained the same)

\begin{tabular}{|c|c|c|c|c|c|c|c|c|}
\hline \multirow[b]{2}{*}{ Scale } & \multicolumn{3}{|c|}{ Country } & \multicolumn{3}{|c|}{ Age Group } & \multicolumn{2}{|c|}{ Sex } \\
\hline & U.S.A. & Spain & $\begin{array}{c}\text { West } \\
\text { Germany }\end{array}$ & Younger & $\begin{array}{c}\text { Middle- } \\
\text { Aged }\end{array}$ & Older & Males & Females \\
\hline Predictable (Absolute) & 4.07 & 3.73 & 3.85 & 3.55 & 3.92 & 4.18 & 3.87 & 3.90 \\
\hline Safe (Absolute) & 1.42 & 3.82 & 1.25 & 3.80 & 4.27 & 4.42 & 4.18 & 4.15 \\
\hline Relaxed (Absolute) & 3.70 & 3.57 & 3.70 & 3.52 & 3.73 & 3.72 & $\underline{3.86}$ & $\underline{3.46}$ \\
\hline Mise (Absolute) & 4.07 & 3.92 & 4.15 & $\underline{3.62}$ & 1.10 & $\mathbf{4 . 4 2}$ & 3.94 & 4.14 \\
\hline Considerate (Absolute) & 4.27 & 4.00 & 4.25 & 3.93 & 4.17 & 1.42 & 4.20 & 4.14 \\
\hline Responsible (Absolute) & 4.62 & 4.25 & 4.45 & 4.15 & 4.50 & 4.67 & 4.47 & 4.41 \\
\hline Predictable (Relative) & 3.77 & 3.77 & 3.57 & 3.47 & 3.75 & 3.88 & 3.72 & 3.68 \\
\hline Safe (Relative) & $\underline{4.20}$ & 3.90 & 3.62 & 3.70 & 3.98 & 4.05 & 3.96 & 3.87 \\
\hline Relaxed (Relative) & 3.52 & 3.43 & 3.58 & 3.37 & 3.48 & 3.68 & $\underline{3.72}$ & 3.30 \\
\hline Wise (Relative) & 3.87 & 3.87 & 3.83 & $\underline{3.50}$ & $\underline{1.05}$ & 1.02 & 3.88 & 3.83 \\
\hline Considerate (Relative) & 4.05 & 3.87 & 3.95 & $\underline{3.75}$ & $\underline{3.92}$ & 1.20 & 3.98 & 3.93 \\
\hline Responsible (Relative) & 4.08 & 3.93 & 3.93 & 3.72 & 4.08 & 4.25 & 4.01 & 3.96 \\
\hline Driving Skills (Absolute) & 4.12 & 3.57 & $\underline{3.68}$ & 3.63 & 3.90 & 3.83 & 3.91 & 3.67 \\
\hline Driving Skills (Majority) & 3.20 & 3.00 & 3.25 & 2.92 & 3.20 & 3.33 & 3.12 & 3.18 \\
\hline
\end{tabular}

both in relation to driving (Svenson 1981; McCormick et al. 1986) and to other abilities (Brown 1986; Regan, Gosselink, Hubsch, and Ulsh 1975; Tränkle and Bailer 1988).

\section{Effects of country}

The distributions of responses differed across the three countries for the following eight scales: predictable (absolute), safe (absolute and relative), considerate (absolute and relative), responsible (absolute), and driving skills (absolute and majority). In general, Spanish drivers tended to place themselves more frequently in middle response categories than did U.S. subjects. Conversely, U.S. subjects tended to place themselves more frequently in positive response categories than did Spanish subjects. The pattern of responses of West German subjects fell in between the patterns of Spanish and U.S. subjects, but it more approximated the pattern of responses of U.S. subjects.

A slightly different picture emerges when means of response distributions are compared. (A difference in the distributions of responses is not a sufficient condition for differences in mean responses, and vice versa.) The analyses of variance showed that there were differences among the countries on 4 out of 14 scales. These scales were the following: safe (absolute and relative), responsible (absolute), and driving skills (absolute). For all four of these scales, U.S. subjects rated themselves most positively. Spanish subjects rated themselves least positively, with the exception of the safe (relative) scale, for which West German subjects assessed themselves least positively.

When the effects of driving experience were controlled for in the analyses of covariance, all the significant effects of country remained significant, with the exception of the responsible (absolute) scale. (Although there is no evidence in this direction, it 
cannot be excluded that the presumed effects of country are due to differential subject sampling.)

\section{Effects of age}

The results of the analyses of variance indicate that the effect of age was present for 12 out of the 14 scales, the two exceptions being both relaxed scales. In general, older subjects tended to assess themselves most positively, followed by middle-aged subjects, and younger subjects. However, the primary difference was between younger subjects and the combined group of middle-aged and older subjects.

When controlling for the effects of driving experience, significant effects of age remained only for three scales: wise (absolute and relative), and considerate (relative). Since years of driving experience was strongly correlated with age group $(r=.83)$, an absence of significant effect of age group in a particular analysis of covariance could be a consequence of this high correlation. (The remaining intercorrelations between the covariates and the independent variables were more modest: -.20 for years of driving by country, -.04 for years of driving by sex,-.05 for annual amount of driving by age group, -.01 for annual amount of driving by country, and -.32 for annual amount of driving by sex. Consequently, an absence of a significant effect of country [see above] or sex [see below] in a particular analysis of covariance cannot be attributed to a strong correlation between the independent variable in question and a covariate.)

\section{Effects of sex}

In the analyses of variance, the effect of sex was significant for three scales: both relaxed scales (these were the only scales with no age effect), and driving skills (absolute) scale. In all three cases, males assessed themselves more positively than did females. The three significant effects remained significant even after controlling for the effects of driving experience in the analyses of covariance.

\section{Absolute vs, relative self-assessment}

Subjects tended to assess themselves positively, whether asked for evaluation on an absolute basis or in relation to the average driver. However, a direct comparison of the absolute and relative responses would not be very meaningful, since the two sets of questions used slightly different adjectives for the scale points.

\section{Self-assessment vs, assessment of others}

Drivers in all three countries assessed themselves more positively on driving skills than they did the majority of drivers. Furthermore, in all three countries the mean rating of the majority of drivers was close to the middle (neutral) category.

Acknowledgements-Appreciation is extended to John H. Chambers, Michael J. Flannagan, A. Regula Herzog, and Paul $\mathrm{L}$. Olson for their assistance and advice in conducting this research. This research was supported, in part, by the U.S.-Spain Joint Committee for Scientific and Technological Cooperation in Madrid, Spain.

\section{REFERENCES}

Brown, J. D. Evaluations of self and others: Self-enhancement biases in social judgments. Social Cogn. 4:353$377 ; 1986$.

McCormick, I. A.; Walkey, F. H.; and Green, D. E. Comparative perceptions of driver ability-a confirmation and expansion. Accid. Anal. Prev. 18:205-208; 1986.

Regan, J. W.; Gosselink, H.; Hubsch, J.; Ulsh, E. Do people have inflated views of their ability? J. Personal. Social Psychol. 31:295-301; 1975.

Sivak, M.; Soler, J.; Tränkle, U. Cross-cultural differences in driver risk-taking. Accid. Anal. Prev. 21:363$369 ; 1989$.

Sivak, M.; Soler, J.; Tränkle, U.; Spagnhol, J. M. Cross-cultural differences in driver risk-perception. Accid. Anal. Prev. 21:355-362; 1989.

Svenson, $O$. Are we all less risky and more skillful than our fellow drivers? Acta Psychol. 47:143-148; 1981

Tränkle, U.; Bailer, H. Besser als (fast) alle anderen? Über das positive Selbstbild von Autofahren und was es bedeutet. (Better than (almost) everybody else? On the positive self-evaluation of drivers and its meaning.) Zeitschrift für Verkehrssicherheit. 34:148-151; 1988. 